\title{
Corruption in Brazilian Public Administration: A Study on the Perception of Law Enforcement Agents
}

\author{
Camilla Fernandes \\ Administration Graduate Program, Federal University of Paraná, Curitiba, Paraná, \\ Brazil
}

Bernardo Meyer

Administration Science Department, Federal University of Santa Catarina, Florianópolis, Santa Catarina, Brazil

Received: May 16, 2018 Accepted: June 3, 2018 Online published: June 6, 2018

doi:10.5296/jpag.v8i2.13256

URL: https://doi.org/10.5296/jpag.v8i2.13256

\begin{abstract}
Corruption is a complex phenomenon that confronts all types of organizations. It also takes place in the underground of the organizational life. However, due to the difficulty in obtaining data it is not as researched and studied as it should be in organizational studies. The goal of this paper is to analyze the corruption in Brazilian public administration based upon the perception of law enforcement agents. The paper is based on qualitative research which used primary and secondary data, however most part of the data was obtained in depth interviews with 12 Brazilian law enforcement agents. The results of the research point out seven main findings. The interviewees also highlighted that corruption can be seen in all areas of citizen's life, including in daily practices, so it is important to find new forms to combat Transparency, greater social participation, control and punishment were listed as the main elements to be explored in the fight against corruption. The main contribution of this article is to discuss the limitations of the rationality of law enforcement agents in relation to a complex phenomenon, as corruption in public administration, in a country with high corruption incidence, as Brazil.
\end{abstract}

Keywords: corruption, Brazilian public administration, law enforcement agents

\section{Introduction}

Corruption is a complex phenomenon that confronts all types of organizations and that produces many relevant implications, but is not as researched and studied as it should be in organizational studies. This can be partially explained by the fact that corruption is something 
that takes place in the underground of the organizational life and that is difficult to obtain data about it.

In Brazil, this pattern is not any different. Although there has been a great deal of political debate regarding corruption in public administration, there has not been many publications addressing this topic in the field of administration and organizational studies in local publications.

The complexity of corruption as an organizational phenomenon has many sources, intervenients, and consequences (Misangyi, Weaver \& Elms, 2008; Rose-Ackerman \& Palifka, 2016). It is commonly attributed to historical and cultural factors, but not limited to these two important components.

It is also a phenomenon that generates many negative effects to society, although there are always individuals or groups that benefit from it. Therefore, there is a strong incentive to eliminate it from organizations, and specially, from public administration. It should be noted that corruption is not only a problem of underdeveloped countries, as it occurs also in the developed world.

In Brazil recently corruption in government received a great deal of attention from media, due to major stinging operations lead by Federal Police and Federal Prosecution Service. In fact, it seems that corruption found in Brazil good ambience which led to its widespread.

The purpose of this paper is to advance the understanding on corruption in Brazilian public administration by analyzing it based on the perception of law enforcement agents. In order to do so, the researchers used an in depth qualitative methodology, based in primary and secondary data. This paper is based mainly on the theoretical contributions of Rose-Ackerman \& Palifka (2016), Pinto, Leana \& Pil (2008) on corruption and Faoro (2001) and Ribeiro (2004) on corruption in Brazil.

\section{Corruption}

It is necessary to recognize that corruption is a multidimensional and an old phenomenon that can appear in organizations of any nature, either public or private and that can be considered a modern organizational world problem (Miari, Mesquita \& Pardini, 2015).

Analyzing this phenomenon on an individual basis, it is possible to think that the moral values of each person should prevent corruption from happening (Rose-Ackerman, 2016), however it is not that simple. Another interesting element is that corruption has different meanings and interpretations, which also vary according to time and space (Rose-Ackerman \& Palifka, 2016), and also from individual to individual.

Corruption is a phenomenon that is defined in different forms. According to different perspectives the term also can have different interpretations. Corruption can be defined as the act of corrupting, which is considered a very old effect of human nature, permeating ideologies, government spheres and political regimes, making itself present in all periods of human history (Ribeiro, 2004). Corruption is also defined objectively as the misuse of public office for private gain (Rose-Ackerman, 2008). 
Corruption generates many negative effects and is seen as an obstacle to sustainable development, causing inefficiency, inadequate incentives for economic investments, and consequently, can discourage the population in the search for the common good. It can generate social, economic and political costs (Santos, Guevara \& Amorim, 2012).

Corruption is considered a cultural problem, but also a political and economic problem (Rose-Ackerman \& Palifka, 2016). The phenomenon is also related to the institutional logics that surround it, therefore it relates to social actors, values and beliefs and institutions (Misangyi, Weaver \& Elms, 2008). There is no one single reason that is able to explain by itself the corruption phenomenon.

It should be noted that corruption is not only a problem of underdeveloped countries, as it occurs also in the developed world. Although its effects are more evident in developing countries, corruption is also present in developed countries, especially in those that do not have transparency in government so widely disseminated (Transparency International, 2017). Italy, for example, is considered a developed European country that tolerates high levels of corruption in public administration (Chemin, 2017). The causes and consequences of corruption can differ from country to country and so does its effects (Brei, 1996; Khan, 1996).

Corruption can be analyzed according to three perspectives (Berkovich, 2015):

(a) Normative perspective: suggests that corrupt acts deviate from the dominant conceptions held by the relevant public. This perspective encompasses deviations from ethical standards, as well as actions are contrary to the public interest (Khan, 1996);

(b) Positivist perspective: suggests that corrupt acts can be acknowledged only by their consequences. In this perspective corruption is seen as deviations from legal norms (Khan, 1996);

(c) Legal perspective: suggests that corrupt acts deviate from formal regulations and exceed permitted standards.

Corruption in organizations can also be classified in two different forms: (a) corrupt individuals: individuals acting corruptly for their own benefit, and; (b) corrupt organization: where the whole group acts corruptly together, in order to benefit the organization (Pinto; Leana \& Pil, 2008).

Corruption can take place in different types of organizations. However, corruption in governmental organizations tends to have larger impact over society. When there is corruption in government citizens perceive that public administration is going all wrong which ends up undermining its effectiveness and legitimacy (Rose-Ackerman \& Palifka, 2016).

Government corruption involves politicians or administrators using their decision power and public resources for their personal gain (Rodriguez, Uhlenbruck \& Eden, 2005). In these cases, as an individual interest takes precedence over the public interest, it ends up resulting in resource deviation and, generally, also to a decrease in governmental resources. 
Consequently, this process can lead to low quality in public services.

Government corruption also has an indirect effect on the effectiveness of public services. For example, when government corruption leads to low-quality services, some individuals withdraw from these services and refuse to pay for them, thereby diminishing the reach of its public policies (Gupta, Davoodi \& Tiangson, 2000).

The practice of corruption can also be associated with its cost-benefit. There are several penalties for individuals caught in corrupt practices, but the assumption is that a person will be involved in corruption if the benefits out of it are greater than the costs (Kingshott \& Dincer, 2008).

Heidenheimer (1970) explains that corruption can be conceptualized according to the perception of social actors. According to this approach, corruption can be classified as white, black and gray corruption.

White corruption refers to tolerance when the law typifies a particular act as a crime, but there may be a disagreement over socially accepted norms of tolerance. White corruption is the extreme opposite of black corruption, as laws disapproves theses acts, social norms tolerate it or even recognize it morally questionable (Borini \& Grisi, 2009; Araújo, 2014).

On the other hand, black corruption happens when the law and the social norm coincide and reprove the corrupt acts. Then, there is a synergy between existing perceptions in society and the legal terms. In black corruption, the law punishes and society believes that corrupt act should be punished (Araújo, 2014). In conclusion, black corruption is characterized as corrupt practices such as illegality, which is punished severely by law and by society, as examples are cited robbery, evasion and bribery.

Finally, gray corruption occurs when there is no consensus between legal and social perceptions (Santos; Guevara \& Amorim, 2012). Gray corruption will exist when the individuals in a given society evaluate a certain corrupt behavior in a controversial way (Araújo, 2014). Gray corruption can be exemplified by informal businesses, which, far from being inspected, sell and buy illegal products, practicing illegal competitive maneuvers to earn profits (Santos; Guevara \& Amorim, 2012). This approach reveals clearly that corruption is not something so easy to be identified and consequently combated.

In an interesting study on corruption in state owned enterprises that provide water and electricity services in Karachi, Pakistan, Rafi, Lodi \& Hasan (2012), revealed that corrupt practices are an embedded practice that will be difficult to remove. However, the same authors point out several measures that can be adopted to reduce corruption in public administration, starting with the most important one: the political will to do so.

It should be pointed out that corruption can benefit an organization, by giving access to resources, and can also damage when it is a victim of corrupt practices by an employee or by third parties (Pinto; Leana \& Pil, 2008). In order to prevent corruption in organizations, managers developed a wide variety of controls which combined or isolated produce also different results (Lange, 2008). 
Ethical dilemmas are present in the management of organizations. Therefore, in the current competitive environment, the current impression is that an executive no longer runs the company in favor of the consumer, shareholders or employees. The executive aims, above all, ambition and own financial profit (Handy, 2005). Thus, there is a clear need to use policies, strategies and actions to prevent and avoid the occurrence of corrupt practices in public administration.

\section{Corruption in Public Administration in Brazil}

In the last few years, Brazil has been impacted with anti corruption operations and corruption charges against politicians and public administrators. This theme was highlighted when social demonstrations demanding the end of corruption in public administration became more frequent and gained strength all over the country, reaching historical records.

Corruption in Brazilian public administration was highlighted by an investigation led by Brazilian law enforcement agencies, called Lava Jato Operation, which revealed a network of corrupt practices among politicians and private firms involving commercial relations with the giant Brazilian oil drilling state owned enterprise Petrobras. It has been considered as the biggest investigation of corruption and money laundering that Brazil has ever had (Federal Prosecution Service, 2016; Chemin, 2017).

The Lava Jato Operation estimated that the volume of resources diverted from the Petrobras by corruption is around US $\$ 430$ million dollars (Federal Prosecution Service, 2017). Some numbers can show the dimension of this national wide stinging operation: (a) it has already initiated 1.433 investigation procedures; (b) it has completed 767 search and seizure orders, (c) it has initiated 61 criminal charges against 269 people; (d) it has produced 29 people sentenced for crimes of corruption, criminal organization, and others crimes; (e) it has produced also 94 preventive prisons warrants and 103 temporary prisons warrants (Federal Prosecution Service, 2017).

The extension and depth of corruption in Brazilian causes perplexity even in the most callous observers (Ribeiro, 2004; Lara Resende, 2015). Brazilians used to be complacent with small transgressions and corruption as itself has always existed (Ribeiro, 2004). However, it has reached a point that corruption seems institutionalized and the seriousness of the situation ended up bringing serious impacts on the national economy and its politics. This situation has been one of the main reasons that led Brazilians to the streets again in several manifestations.

Famous corruption stinging operations, such as Lava Jato in Brazil and Mani Puliti in Italy, have shown a great deal of similarities and that, most of the times, connects the government authorities with private companies (Bezerra, 1995; Chemin, 2017). In fact, these informal relations between public administration and private enterprises end up developing the so-called crony capitalism (Lazzarini, 2011).

The growth of corruption in the last few years coincides with the reestablishment of the democratic regime, however, it should be highlighted that the democratic advance in Brazil is also an important factor to combat corruption, starting from the premise that interests of the collectivity must overlap the particular ones (Ribeiro, 2004). 
Democracy brings also an interesting approach to corruption. Using data from Spain, Cordero \& Blais (2017) found out that corrupt governments are not always punished by voters and under certain circumstances voters vote in politicians or parties even if the party is perceived as corrupt. These authors argue that voters judge corruption in relative terms, so what really matters is not how corrupt the politician or the party is perceived, but whether if he is considered more corrupt than the other parties. In this process, transparency in public administration is a major instrument for economic and social development along to the democracy consolidation (Raush \& Soares, 2010).

One common source of corruption is related to electoral campaign contributions, as private organizations search for contracts with public administration and sometimes do not measure the means to obtain them. Authors, as Claessens, Feijen \& Laeven (2008) and Reis, Meyer Jr. $\&$ Meyer (2012), show that electoral campaign contributions are an effective form of political strategy in Brazil, as companies increase their capability of influencing political actors in order to further their interests and end up generating a better adjusted environment to their needs, improving their competitiveness. However, it is important to highlight that political campaign contributions are not always associated to corruption.

Until recently Brazilian electoral legislation allowed business financing in political campaigns. Authors, such as Bezerra (1995) and Claessens, Feijen \& Laeven (2008), believe that this type of interference of the private sector is not only bad for democracy, but also a source of corruption and cronyism, as politicians begin their terms with "debts" with those who payed for their campaign.

In Brazil, corruption is even deeper than one could imagine and, only a small part of the cases probably will be discovered and came out to the public (Ribeiro, 2004). Brazilian culture is based on patrimonialism, favoritism and paternalism, generated favorable conditions to corruption. These characteristics are typical of the patrimonial state introduced by Portuguese colonizers and that still are very present in Brazil (Faoro, 2001).

Theoretically, public managers, acting in the name of the public administration, can only perform acts when supported in previous legal determination. It has been verified that there are still great challenges to rationalization and develop efficiency in the use of public resources in order to fulfil the objectives of the public administration in the country.

\section{Research Method}

This research is based on qualitative research strategy in order to achieve an in depth study and better understand the subjectivity of the perception of law enforcement agents (Creswell, 2014) regarding corruption in public administration. Based upon this subjetivistic approach the authors intended to penetrate in the interpretation that law enforcement agents have of this phenomena.

In order to achieve this objective, the researchers based the study on primary and secondary data. The primary data was based on personal interviews with semi-structured questionnaires with 12 law enforcement agents at the municipal, state and federal levels of Brazilian public administration working in the States of Santa Catarina and Paraná. The researchers chose 
these interviewees randomly and upon convenience.

Personal interviews with semi-structured questionnaires give flexibility to the interviewer in order to understand how the interviewer thinks and interpretates reality (Yin, 2001). The interviews were all conducted face to face by one of the researchers and were also recorded and transcribed to allow a better organization of all the information.

In order to access the perception of law enforcement authorities on corruption, the researchers interviewed 12 law enforcement agents, among them Police Authority, Public Prosecutors, Judges, Public Auditing Authority. The interviewees were selected randomly and were all law enforcement authorities that work for Brazilian national and subnational (State and city level) government. The actors were also selected based on the criteria of convenience and representativeness. These professionals were chosen because of their work directly with situations connected to corruptions and, therefore, know the idiosyncrasies of this phenomenon.

It is relevant to highlight that Law enforcement agents interviewed in this study were chosen also to represent the three levels of Brazilian Federation, municipal, State and National, in order to increase the representativeness of the study and to identify the similarities and differences in their perceptions.

It should be noted that all the interviewees are public servants, however, the respondent 7 was interviewed in the position of Vice President of the Social Observatory of the city of São José, which is a non-profit institution which inspects the City Hall. This specific interviewee is also an internal auditor of the government of the State of Santa Catarina. Table 1 details the profile of the interviewees:

Table 1. Interviewees' profile

\begin{tabular}{|c|c|c|c|c|c|}
\hline Interviewee & $\begin{array}{c}\text { Academic } \\
\text { Background }\end{array}$ & Age & $\begin{array}{l}\text { Time in } \\
\text { function }\end{array}$ & Position & Organization \\
\hline $\begin{array}{c}\text { Interviewee } \\
1\end{array}$ & Law & 38 years & 13 years & Police Chief & Federal Police \\
\hline $\begin{array}{c}\text { Interviewee } \\
2\end{array}$ & Law & 35 years & 2 years & $\begin{array}{c}\text { Compliance } \\
\text { Manager }\end{array}$ & $\begin{array}{c}\text { Eletrosul (State } \\
\text { Owned Enterprise) }\end{array}$ \\
\hline $\begin{array}{c}\text { Interviewee } \\
3\end{array}$ & Law & Not informed & 10 years & Fiscal Auditor & $\begin{array}{c}\text { State of Santa } \\
\text { Catarina Audit } \\
\text { Office }\end{array}$ \\
\hline $\begin{array}{c}\text { Interviewee } \\
4\end{array}$ & Law & Not informed & 14 years & Police Chief & $\begin{array}{c}\text { State of Santa } \\
\text { Catarina Police }\end{array}$ \\
\hline $\begin{array}{l}\text { Interviewee } \\
5\end{array}$ & $\begin{array}{c}\text { Business } \\
\text { Administration }\end{array}$ & 43 years & 5 years & Fiscal auditor & $\begin{array}{c}\text { State of Santa } \\
\text { Catarina Audit } \\
\text { Office } \\
\end{array}$ \\
\hline $\begin{array}{c}\text { Interviewee } \\
6\end{array}$ & $\begin{array}{c}\text { Business } \\
\text { Administration, } \\
\text { Law and } \\
\text { Accounting } \\
\end{array}$ & 40 years & 18 years & Fiscal auditor & $\begin{array}{l}\text { State of Santa } \\
\text { Catarina Audit } \\
\text { Office }\end{array}$ \\
\hline $\begin{array}{c}\text { Interviewee } \\
7\end{array}$ & Accounting & 41 years & 6 years & Vice-President & $\begin{array}{c}\text { Social Observatory } \\
\text { of the City of São } \\
\text { José }\end{array}$ \\
\hline $\begin{array}{c}\text { Interviewee } \\
8\end{array}$ & $\begin{array}{l}\text { Computer } \\
\text { science }\end{array}$ & 39 years & 10 years & $\begin{array}{l}\text { Chief of } \\
\text { Internal } \\
\text { Auditing }\end{array}$ & São José City Hall \\
\hline
\end{tabular}




\begin{tabular}{c|c|c|c|c|c}
\hline $\begin{array}{c}\text { Interviewee } \\
9\end{array}$ & Law & 37 years & 10 years & $\begin{array}{c}\text { Public } \\
\text { Attorney }\end{array}$ & $\begin{array}{c}\text { State of Santa } \\
\text { Catarina Public } \\
\text { Prosecutor Service }\end{array}$ \\
\hline $\begin{array}{c}\text { Interviewee } \\
10\end{array}$ & $\begin{array}{c}\text { Business } \\
\text { Administration } \\
\text { and Law }\end{array}$ & 47 years & 12 years & Attorney & $\begin{array}{c}\text { State of Santa } \\
\text { Catarina Audit } \\
\text { Office }\end{array}$ \\
\hline $\begin{array}{c}\text { Interviewee } \\
11\end{array}$ & Law & 49 years & 19 years & Judge & $\begin{array}{c}\text { State Justice of Santa } \\
\text { Catarina }\end{array}$ \\
\hline $\begin{array}{c}\text { Interviewee } \\
12\end{array}$ & Law & 36 years & $\begin{array}{c}2 \text { years } \\
\text { and } 10 \\
\text { months }\end{array}$ & $\begin{array}{c}\text { Public } \\
\text { Attorney }\end{array}$ & $\begin{array}{c}\text { State of Paraná } \\
\text { Public Prosecutor } \\
\text { Service }\end{array}$ \\
\hline
\end{tabular}

Source: Primary data

The primary data collected in the interviews was organized in categories and confronted with the secondary ones, obtained mainly from official sources and information published in the media. The analysis and confrontation was made with the use of pattern matching (Trochim, 1989).

This study focuses on a phenomenon of difficult verification and primary data collection. This occurs because corruption is an illegality and people do not speak openly about it. For this reason, the research was based on strategy that focuses on the perceptions of public agents on the subject.

\section{Analysis and Data discussion}

\subsection{Corruption in Brazilian Public Administration}

Corruption is certainly a major problem in many countries, especially when considering public administration (Miari; Mesquita \& Pardini, 2015). Corruption was pointed out unanimously as one of the most alarming problems in the Brazilian public administration by all the interviewees. Its existence in public organizations generally affects a whole mass of people who suffers from its various effects.

Interviewee 11 made a strong statement as he affirmed that corruption is one of the major reasons behind Brazil's social inequality, since it developed itself because of the way the Brazilian State was constituted (Ribeiro, 2004; Rausch \& Soares, 2010). In Interviewee's 3 view, corruption is an endemic problem in Brazilian public administration because it is part of the culture of this sector. This view was also endorsed by other interviewees, such as interviewees 10 and 7. The wide spread of corruption in Brazil was related to the cultural practice of "jeitinho brasileiro", which brings up the idea of taking advantage of others (Interviewee 7).

In Brazil, certainly corruption found conditions that enabled its development. Interviewee 10 stated that "corruption is in Brazilians' life every day". Interviewee 12 went further and explained that "corruption is not an exclusively Brazilian phenomenon, but certainly the impunity and patrimonialism of the country have made a fertile field for its dissemination".

For Interviewee 5, corruption has to do with the way society views public administration and countries with higher levels of development have a clearer understanding of public service and citizenship. Therefore, corruption does not find the adequate environment to flourish. 
These statements show clearly that corruption is attributed to historical, institutional and cultural factors (Faoro, 2001; Ribeiro, 2004; Rausch \& Soares, 2010).

Corruption brings a number of negative consequences to any country and in Brazil it is not any different (Ribeiro, 2004; Transparency International, 2017). An important one is related to economic issues. In Brazil, corruption affects the country's economy as it influences the company's confidence to invest (Interviewee 2). Lack of confidence is a driver that influences the entire market, which increases the difficulty for companies to finance new investments (Santos, Guevara \& Amorim, 2012; Rose-Ackerman \& Palifka, 2016).

Regarding all the recent corruption scandals that received vast media coverage, all the interviewees emphasize that the phenomenon has been occurring for long time in the country, what changed was the level of disclosure. Interviewee 5 reinforced that: "Only now culture is changing and corruption is being viewed as wrong" (Ribeiro, 2004; Lara Resende, 2015).

Corruption has its origin attributed to many different sources (Rose-Ackerman \& Palifka, 2016; Brei, 1996; Khan, 1996). One of the sources of Brazilian corruption culture was traced to education. There is a lack of civic education throughout primary and secondary education, which ends up reflecting in the conduct and ethics in adulthood, as the absence of a specific civil formation and the lack of knowledge about the importance of life in society contributes to deviations of conduct (Interviewee 6).

Another reason behind corruption can be attributed to the lack of professionalism in Brazilian public service (Interviewee 8). The interviewee believes that this situation leads to a problem which is that the public resources are not being invested correctly (Gupta, Davoodi \& Tiangson, 2000).

Other reason that stimulates the existence of corruption is the country's political system (Interviewee 9). This law enforcement agent states that the political system is fed and only moves when motivated by the forces of corruption, which was confirmed by the investigations of Lava Jato Operation (Rodriguez, Uhlenbruck \& Eden, 2005).

The Brazilian electoral system has also been described by several interviewees as one of the biggest causes of corruption in Brazil. The cost of the Brazilian electoral process was singled out as one of the main causes of corruption in the country. Interviewees 2 and 10 emphasized that Brazilian political campaigns are based in millionaire spendings. Disagreeing with this view, interviewee 2 pointed out that private money to fund campaigns is not the main problem, but the money that is used for illicit enrichment (Rodriguez, Uhlenbruck \& Eden, 2005; Santos; Guevara; Amorim, 2012).

Interviewee 1 emphasized that political campaign financing gives more access to politicians. In her own words: "If you financed someone, you will have more access to that person and he will eventually defend your interests" (Bezerra, 1995; Claessens, Feijen \& Laeven, 2008; Reis; Meyer Jr. \& Meyer, 2012). Interviewee 7 agreed with the point and completed: "The limitation of donations per juridical person was an evolution, because previously the collection of resources was an advanced lobby". 
Interviewee 9 pointed out that in the election of 2016, the campaign times were reduced and, in general, there were cheaper campaigns. The same interviewee highlighted "we should now check if cheaper campaigns have generated more honest management".

A real example was Federal Police's Ararath Operation when it investigated corruption in public administration and money laundering. It found out a criminal organization that involved politicians, public administrators and businessmen, who managed funds for corrupting public agents, illegal financing of electoral campaigns and also fraudulent management (Federal Revenue Service, 2016).

\subsection{Preventing Corruption}

In order to avoid the wide spread of corrupt practices, governments have been developing a number of initiatives to avoid them (Lange, 2008). Interviewee 1 highlighted control mechanisms are stronger in federal government, than in subnational government. The same interviewee also pointed out that when an organism has less control, the greater the probability of deviations occurring. Interviewee 2 agreed with this view and emphasized that corruption occurs precisely when there is a combination of opportunity and lack of control.

Four of the interviewees pointed out that there are several examples of countries that reach a good level of efficiency in the fight against corruption. In this sense, interviewee 2 highlighted that "The Nordic countries in the anti-corruption indexes are always the best ones". The same interviewee justified that this fact is often due to local culture, educational levels and also to the implementation of state and corporate controls (Brei, 1996; Khan, 1996; Chemin, 2017). This interviewee also mentioned Chile as a country that in the last few years developed new control systems in public administration and also more strict procedures to select high level government officers.

Several interviewees quoted as examples of anti-corruption countries the Asian ones. Interviewee 3 affirmed that moral and ethical values are very different from one country to another, especially in relation to impunity. According to interviewee 5, in Brazil because of "impregnated customs" it is hard to defeat corruption, therefore there is a need to use more "harsh" ways of rebuke.

Interviewee 9 attributed this characteristic to the fact that "some countries have already practiced the culture of transparency for years. While in Brazil the transparency law exists since 2011, these countries have made public their records of information for many years". According to interviewee 10, the widespread culture of corruption pervades society, and what differs from one country to another are the levels of combat and prevention practices (Rose-Ackerman; Palifka, 2016).

Four of the interviewees pointed that the main effect of corruption is lowering the quality standard of services provided to society (Gupta, Davoodi \& Tiangson, 2000; Rodriguez, Uhlenbruck \& Eden, 2005; Berkovich, 2015). Interviewee 4 explains the following fact: "Let's say a bridge costs 1 million reais and goes out for 3 million in a government acquisition process. There are two million reais which aren't going to finance services to the community". Interviewee 10 highlighted the idea as a "paradox", stating that as the state 
loses its efficiency, it becomes very expensive and "takes away many resources from the economy and does not returning good services".

A good example of how corruption occurs in Brazil was given by Interviewee 4. He mentioned a case where he received a complaint that a public employee would be asking for money to approve people in the National Driver's License qualification test. According to the interviewee, an investigation was carried out and the occurrence was identified. Within the investigation, there was a police inquiry and the corrupt was temporarily detained. Interviewee 4 affirmed that today, the person is free although it was proven that there was corruption. In his view, corrupts should not go free so easily.

This interviewee also mentioned another example where there was a gang inside the State government, which diverted loads of grains from public warehouses. The loads of grains were not getting to its destination because there was robbery plan in action. The interviewee mentioned that, through the investigation, it was verified that a public agent was assisting the gang with information. In this operation, according to the interviewee, there was the arrest of all involved and "the case had a more consistent endorsement".

Three interviewees stressed that the key for change is the human being and everyone that takes an office position in the public sector, must have a very strong ethics, otherwise it will be very easy to be corrupted (Rose Ackerman \& Palifka, 2016). Interviewee 9 highlighted punishment, stressing that is necessary improve mechanisms of repression with more severe penalties and faster processes (Kingshott \& Dincer, 2008). Interviewee 6 corroborated with this point and said that "impunity is a great incentive for those who in theory think that in fact, there will never be a consequence for an unlawful act".

Interviewee 7 emphasized that is necessary to increase the existing level of inspection and affirms that public control entities do not control adequately. According to the same interviewee, there is a "prostitution" of power and increasing enforcement with social participation is paramount in the fight against corruption. Interviewee 8 corroborated with the idea and said that is necessary to end the image that in the country there is no punishment for crimes related to corruption (Kingshott \& Dincer, 2008).

Some interviewees believe that changes in legislations can help to eliminate or at least reduce corruption from Brazilian public administration. Interviewee 7, with a very strong position, stated that existent laws need to be improved, but, stressed that society needs to know how to use existing laws and highlighted: "those who do not like the laws, are the corrupt".

Interviewee 9 affirmed that the existing laws in the country are imperfect and can be improved, pointing out that, the criminal enforcement system in Brazil is very mild and would require a legislative change. On the other hand, Interviewee 1 pointed out that "the existing rules are enough" and inserting new measures and laws will not necessarily reduce corruption.

In this behalf, an interesting example was given when President Dilma Rousseff approved a law that became known as the "Anti Corruption Law" in 2013. This legislation represented an advance in terms of punishing business and businessmen involved with corruption in dealings 
with the public sector. Dichotomically, the government of President Rousseff got involved, three years after the adoption of this law, in a large corruption scandal.

In order to complement the existing legislation, the Federal Prosecution Service (2017) created a legislative proposal called "10 Measures Against Corruption". It has the objective to end the vicious circle of corruption in the private and public area through systemic and structural changes, aiming on transparency, prevention, punishment, efficiency and effectiveness.

When asked about the 10 Measures against Corruption there were contradictions among the different interviewees. While the majority emphasized the positive aspects that this legislative initiative would generate. Others offered some critics and mentioned the measures would not be effective (Interviewee $1 \&$ Interviewee 11), one mentioned it would not attack the origin of corruption, but its consequences (Interviewee 6). Interviewees 1 and 7 believe some measures are excessive. According to Interviewee 11, with the application of the measures, the country would return to "a very primitive process, from the Middle Ages, at the time of the inquisition" reinforcing the idea that the combat should start from the people and stressed that she does not believe in criminal law as an effective way of fighting corruption.

Two interviewees mentioned that social control is another form to combat corruption and is also a duty of all citizens. As an example, interviewee 7 mentioned the case of a Non Profit Organization called The Social Observatory of São José, in Santa Catarina, whose main mission is to fight corruption and inefficiency in the City Hall in a preventive way, supervising laws, decisions, and processes before they become active.

Another interesting case was mentioned by Interviewee 1 when she was in charge of an important operation of the Federal Police in the city of Florianopolis, which led to the arrest of innumerable businessmen, politicians and public servants, about 10 years ago. This operation investigated corruption in the environmental licensing of private ventures in the capital of the state of Santa Catarina. In her investigation she was able to verify many problems related to process management in the City Hall. In this operation, the investigators found out that there were aldermen who were favoring businessmen to obtain environmental licenses more rapidly and without the proper analysis. Interviewee 1 stressed that: "There are projects that run very fast, out of nowhere, are approved at dawn. Absurd things happened". This investigation also found out cases of alderman whose properties were incompatible with his earnings (Rodriguez, Uhlenbruck \& Eden, 2005), which is a clear example of the normative perspective presented by Berkovich (2015).

The difficulty in accessing public information in this police operation was highlighted by the same interviewee: "at the time of the operation, it was only possible to investigate because of a breach of fiscal confidentiality". Interviewee 1 pointed out that transparency is one of the largest allies in the fight against corruption and currently, with the Transparency Portal, there is already more control.

Transparency, according to all the interviewees, is one of the main targets to be achieved by the Brazilian public administration (Rausch \& Soares, 2010; Transparency International, 2017). The effectiveness of the use of transparency as tool against corruption can be 
exemplified, according to three interviewees, by the fact that since the Federal Government created its Transparency Portal, in 2004, it is possible verify progress in the fight against corruption. The level of transparency in Brazilian sub national governments has also increased and the average of the country's transparency arose almost $33 \%$ in relation to the last research (Federal Prosecution Service, 2016).

Although there has been an evolution in this area, there is still a long way to improve transparency and accountability practices. There is a so called Transparency Law created in 2009, however he stated that the Access to Information Law, created in 2011, but it has not been explored as it should be by the population (Interviewee 9).

These instruments are important to reduce corruption, especially because trusting democracy and voters to fix corruption is idealistic (Cordero \& Blais, 2017). This is can be partially explained by the subjectivity that surrounds corruption, and that makes its interpretation subject to many different factors (Rose-Ackerman \& Palifka, 2016).

An important source of corruption in Brazil is related, in Interviewee 6's view, to fraudulent public procurement. This fact is seen in an operation mentioned by interviewee 9 , where the supplier was the one who elaborated the terms of the public procurement process. This interviewee explained that "It was the supplier who dictated what the City Hall should buy and decided after the contract was signed what would or would not be delivered and no one analyzed whether the product ordered and paid for was the one received".

Although there were many complaints about corruption in Brazil, there has been an evolution in the last few years in terms of corruption prevention and punishment (Interviewee 2). However, this positive information is still contrasted with a high percentage of perceived corruption among its citizens. In research conducted among 176 countries, Brazil ranks in the 80th position, behind countries such as Cuba and Chile (Transparency International, 2017).

\section{Summary and Concluding Remarks}

This research revealed seven interesting results regarding corruption in Brazilian Public Administration. The first finding is that corruption in Brazil is a major problem that has been occurring for long period of time, but that must be reduced or even eliminated as soon as possible. None of the interviewees did present any other point of view and all believe that corruption is bringing very negative consequences not only to the country's public administration, but also to the economy and the society as whole.

A second finding is that corruption is seen not as an exclusively problem of developing countries. The law enforcement agents interviewed unanimously believe that what differs from one country to another are the forms of combating and preventing used by government. This fact can be confirmed in the Transparency International's Annual Corruption Perception Index.

The third finding is that although corruption is a complex phenomenon with multiple forms, sources, intervenients and origins (Misangyi, Weaver \& Elms, 2008; Rose-Ackerman \& Palifka, 2016), most part of the interviewees attributed its origin to cultural, historical, 
institutional, and political patterns, neglecting specially economic and social causes. This evidence shows myopia of law enforcement agents in understanding the causes of corruption.

The forth finding is that the Brazilian electoral system was singled out, by several interviewees, as one of the biggest causes of corruption in Brazil. It was considered a corrupt system in which politicians raise money from businessmen and end up having to work on their interests in public administration (Bezerra, 1995; Claessens, Feijen \& Laeven, 2008; Reis; Meyer Jr. \& Meyer, 2012).

A fifth finding is that inefficiency was pointed as the most evident corruption consequence by all the interviewees. They make justify this point of view by showing that corruption generally deviates resources from its destinations generating lack of resources in many areas and not enabling government to achieve its goals. Along with inefficiency, ineffectiveness is also a problem in Brazilian Public Administration, as government has proven its incapacity to supervise, control and inspect the services it hires and the products that it buys. This lack of supervision also generates corruption as there is little or no control over what is paid and what was is received.

A sixth finding is that the majority of law enforcement agents believe that creating new and tougher legislation against corruption, as well as more punishment, will diminish corruption. This view can be easily understood because of the nature of their work which is related to punishing wrong doings and their Law background. This view is clearly a simplistic and narrow vision of the complex problem of corruption in Brazil. Although, combating corruption and corruptors is important, more laws and more punishment by itself will not reduce corruption in a country that has tolerated it for such a long time (Faoro, 2001; Rafi, Lodi \& Hasan, 2012). This same view was also shared by a few interviewees.

The majority of law enforcement agents interviewed also showed a strong belief in the development of more transparency in public administration and also in improving educational levels as form of helping to fight corruption. Improving transparency certainly is a good measure to avoid hidden practices in public administration (Transparency International, 2017) and Brazil has evolved in this specific point. However, improving education standards is also a good measure to fight corruption, but its effects will be only effective in the long term.

The seventh finding is their unanimous perception that Brazil has shown improvement in combating and preventing corruption. However, they still agree unanimously that there is a long way to go in order to achieve significant results. The preliminary results revealed that there is no country in the world where corrupt practices have been eradicated (Transparency International, 2017), however what differentiates one country from another are the levels of acceptance by the population and the forms of combat and prevention proposed by their governments.

In general, the law enforcement agents interviewed presented a clear understanding of corruption although they were unable to comprehend all its facets. This also reflects in a narrow vision in terms of forms of reducing corruption. However, aggregating all the data given by the interviewees they bring up many important elements to reduce corruption. All 
these elements used together are able to produce a more powerful effect.

\section{Conclusion}

This research brings up seven findings regarding law enforcement agent's views on corruption in Brazil. In general, the interviewees did not show a complete understanding of all the facets that influence corruption, although they work dealing with it very frequently. They neglected in special the economic aspects of corruption (Rose-Ackerman \& Palifka, 2016).

Another important finding is that their view on fighting is majorly based on punitive perspective. Combating corruption and corruptors is certainly important, but more laws and punishment by itself will not reduce corruption in a country that has it as an embedded practice for such a long time (Rafi, Lodi \& Hasan, 2012). The punitive perspective is a manner of attacking the problem, but not the only one or the most important. Complex problems as corruption that also have a variety of components (Misangyi, Weaver \& Elms, 2008; Rose-Ackerman \& Palifka, 2016) cannot be resolved with simplistic solutions.

This vision that the law enforcement agents interviewed presented affect their capacity of reacting to solve the problem and also to propose solutions. However, it can be understood also as a bias of their professional activity, which deals directly in the confronting with corruptors.

On the other hand, the different interviewees presented different ideas of effective forms of fighting corruption practices. In this context, transparency, greater social participation, control and punishment were listed as the main elements to be explored in the fight against corruption.

The main theoretical contribution of this study is the analysis of the vision that those who fight directly corruption have of the phenomenon and understand the limitation of their rationality. This paper brings an important contribution to the field as it reveals the rationality involved in the fight against corruption that is taking place in Brazil in this moment of time. Corruption is a difficult phenomenon to study, due to the difficulty in accessing primary data. However, this study was able to overcome this problem and analyze the perspective of one side.

Regarding the limitations, the study analyzed the managers' perceptions in a specific period: the first half of 2017, which did not allow a longitudinal analysis. In addition, there was the difficulty of obtaining corruption data because it is a phenomenon that exists in the "underground" of organizations, containing elements of illegality in accordance with the legal system of most countries. This fact makes difficult to obtain primary data, since hardly anyone who practices corruption is willing to speak openly about it. The last limitation was the fact that the research has suffered the bias of those who fight against corruption, since it is difficult to collect data by its practitioners.

In order to complement this study, it would be enriching in future studies to learn more about the rationality of law enforcement agents in other countries, as well as the problems that they 
face locally. Another interesting study would be to research people involved in corruption and understand their rationality.

\section{References}

Araújo, R. F. (2014). A percepção de diferentes tipos de corrupção na ótica dos profissionais da contabilidade. Monografia (Especialização) - Curso de Ciências Contábeis, Programa Multiinstitucional e Inter-regional de Pós-graduação, Universidade de Brasília, Universidade Federal da Paraíba e Universidade Federal do Rio Grande do Norte: Natal.

Bercovich, I. (2015). The Corrupted Industry and the "Wagon-Wheel Effect": A Cross-Country Exploration of the Effect of Government Corruption on Public Service Effectiveness. Administration \& Society, 46(5), 1-21.

Bezerra, M. O. (1995). Corrupção: um estudo sobre o poder público e relações pessoais no Brasil. Rio de Janeiro: Dumará.

Borini, F. M., \& Grisi, F. C. (2009). A corrupção no ambiente de negócios: survey com as micro e pequenas empresas da cidade de São Paulo. Revista de Administração, 44(2), 102-117.

Brei, Z. A. (1996). Corrupção: dificuldades para definição e para um consenso. Revista de Administração Pública, Rio de Janeiro, 30(1), 64-77.

Chemin, R. (2017). Mãos limpas e Lava jato: a corrupção se olha no espelho. Porto Alegre: CDG.

Claessens, S., Feijen, E., \& Laeven, L. (2008). Political connections and preferential access to finance: the role of campaign contributions. Journal of Financial Economics, 88(1), 554-580. https://doi.org/10.1016/j.jfineco.2006.11.003

Cordero, G., \& Blais, A. (2017). Is a corrupt government totally unacceptable? West European Politics, 40(4), 645-662.

Creswell, J. W. (2014). Investigação Qualitativa e Projeto de Pesquisa: Escolhendo entre Cinco Abordagens, $3^{\text {a }}$ edição. Porto Alegre: Penso.

Faoro, R. (2001). Os donos do poder: formação do patronato político brasileiro. São Paulo: Globo.

Federal Prosecution Service. (2016). Ranking da Transparência Nacional. Brasília: Brasil. Retrieved September 9, 2016 from: <http://www.rankingdatransparencia.mpf.mp.br/>.

Federal Prosecution Service. (2017). Caso Lava Jato. Brasília: Brasil. Retrieved May 10, 2017 from: <http://lavajato.mpf.mp.br/entenda-o-caso>.

Federal Revenue Service. (2016). Annual Inspection Plan. Retrieved May 12, 2018 from: http://idg.receita.fazenda.gov.br/dados/resultados/fiscalizacao/arquivos-e-imagens/plano-anua 1-de-fiscalizacao-2017-e-resultados-2016.pdf.

Gupta, S., Davoodi, H. R., \& Tiongson, E. (2000). Corruption and the provision of health care and education services (No. 2000-2116). Washington, DC: International Monetary Fund. 
Handy, C. (2005). Pra que serve uma empresa? Rio de Janeiro: Harvard Business Review Campos/Elsevier.

Heidenheimer, A. J. (1970). Political corruption: readings in comparative analysis. New York: Holt, Rinehart and Winston.

Khan, M. H. (1996). The efficiency implications of corruption. Journal of International Development, 8(5), 683-696. Retrieved May 12, 2018 from: http://dx.doi.org/10.1002/(sici)1099-1328(199609)8:53.0.co;2-4.

Kingshott, R. P. J. \& Dicer, O. C. (2008). Determinants of Public Service Employee Corruption: a conceptual model from the psychological contract perspective. Journal of Industrial Relations, 50(1), 69-85. https://doi.org/10.1177/0022185607085695

Lange, D. (2008). A multidimensional conceptualization of organizational corruption control. Academy of Management Review, 33(3), 710-729. https://doi.org/10.5465/amr.2008.32465742

Lara, R. A. (2015). Corrupção e capital cívico. Valor Econômico, Rio de Janeiro, 4-8. Retrieved July 6, 2016 from: <http://www.valor.com.br/cultura/4156904/corrupcao-e-capital-civico>.

Lazzarini, S. G. (2011). Capitalismo de laços: os donos do Brasil e suas conexões. Rio de Janeiro: Elsevier.

Miari, R. C., Mesquita, J. M. C., \& Pardini, D. J. (2015). Eficiência de Mercado e Corrupção Organizacional: estudo dos impactos sobre o valor dos acionistas. Brazilian Business Review, 13(5), 1-6. https://doi.org/10.15728/bbrconf.2015.1

Misangyi, V. F., Weaver, G. R., \& Elms, H. (2008). Ending corruption: the interplay among institutional logics, resources, and institutional entrepreneurs. Academy of Management Review, 33(3), 750-770. https://doi.org/10.5465/amr.2008.32465769

Pinto, J., Leana, C., \& Pil, F. K. (2008). Corrupt organizations or organizational of corrupt individuals? Two types of organization-level corruption. Academy of Management Review, 33(3), 685-709. https://doi.org/10.5465/amr.2008.32465726

Rafi, M. M., Lodi, S. H., \& Hasan, N. M. (2012). Corruption in Public Infrastructure Service and Delivery: the Karachi case study. Public Works Management \& Policy, 17(4), 320-387. https://doi.org/10.1177/1087724X12450642

Rausch, R. B., \& Soares, M. (2010). Controle social na administração pública: a importância da transparência das contas públicas para inibir a corrupção. Revista de Educação e Pesquisa em Contabilidade, 4(3), 23-43. https://doi.org/10.17524/repec.v4i3.250

Reis, J. A. F., Meyer, Jr. V., \& Meyer, B. (2012). Political Strategies and Organizational Effectiveness: The case of contribution to political campaigns by Brazilian Corporations. International Journal of Management and Administrative Sciences, 1(5), 15-26.

Ribeiro, A. S. M. (2004). Corrupção e controle na administração pública brasileira. São Paulo: Atlas. 


\section{Macrothink}

Journal of Public Administration and Governance ISSN 2161-7104 2018, Vol. 8, No. 2

Rodriguez, P., Uhlenbruck, K., \& Eden, L. (2005). Government corruption and the entry strategies of multinationals. Academy of Management Review, 30, 383-396. https://doi.org/10.5465/amr.2005.16387894

Rose, A. S. (2008). Corruption. In: Rowley, C.K., Schneider, F. G. Readings in Public Choice and Constitutional Political Economy. New York: Springer, 551-566. https://doi.org/10.1007/978-0-387-75870-1_30

Rose, A. S. (2016). A moral de cada um tem seu papel, diz estudiosa da corrupção. Estadão: São Paulo. Retrieved August 30, 2016 from: $<$ http://politica.estadao.com.br/blogs/fausto-macedo/a-moral-de-cada-um-tem-seu-papel-dizestudiosa-da-corrupcao/>.

Rose, A. S., \& Palifka, B. J. (2016). Corruption and Government: causes, consequences, and reform. New York: Cambridge University Press. https://doi.org/10.1017/CBO9781139962933

Santos, R. A., Guevara, A. J. H., \& Amorim, M. C. S. (2012). Corrupção nas organizações privadas: Análise da percepção moral segundo gênero, idade e grau de instrução. Revista Administração, São Paulo, 48(1), 53-66. https://doi.org/10.5700/rausp1073

Transparency International. (2017). Corruption Perceptions Index 2016. Retrieved May 21, 2017 from https://www.transparency.org/news/feature/corruption_perceptions_index_2016>.

Trochim, W. M. K. (1989). Outcome pattern matching and program theory. Evaluation and Program Planning, 12, 355-366. https://doi.org/10.1016/0149-7189(89)90052-9

Yin, R. K. (2001). Estudo de Caso: Planejamento e Métodos. Porto Alegre: Bookman.

\section{Copyright Disclaimer}

Copyright for this article is retained by the author(s), with first publication rights granted to the journal.

This is an open-access article distributed under the terms and conditions of the Creative Commons Attribution license (http://creativecommons.org/licenses/by/4.0/). 